\title{
Effects of Long-Term Trampling on the Above-Ground Forest Vegetation and Soil Seed Bank at the Base of Limestone Cliffs
}

\author{
Hans-Peter Rusterholz • Christine Verhoustraeten • \\ Bruno Baur
}

Received: 27 January 2011 / Accepted: 2 July 2011 / Published online: 24 August 2011

(C) Springer Science+Business Media, LLC 2011

\begin{abstract}
Exposed limestone cliffs in central Europe harbor a highly divers flora with many rare and endangered species. During the past few decades, there has been increasing recreational use of these cliffs, which has caused local environmental disturbances. Successful restoration strategies hinge on identifying critical limitations. We examined the composition of aboveground forest vegetation and density and species composition of seeds in the soil seed bank at the base of four limestone cliffs in mixed deciduous forests that are intensively disturbed by human trampling and at four undisturbed cliffs in the Jura Mountains in northwestern Switzerland. We found that long-term human trampling reduced total aboveground vegetation cover at the base of cliffs and caused a significant shift in the plant-species composition. Compared with undisturbed cliffs, total seed density was lower in disturbed cliffs. Human trampling also altered the species composition of seeds in the soil seed bank. Seeds of unintentionally introduced, stress-tolerant, and ruderal species dominated the soil seed bank at the base of disturbed cliffs. Our findings indicate that a restoration of degraded cliff bases from the existing soil seed bank would result in a substantial change of the original unique plant composition. Active seed transfer, or seed flux from adjacent undisturbed forest areas, is essential for restoration success.
\end{abstract}

Electronic supplementary material The online version of this article (doi:10.1007/s00267-011-9727-z) contains supplementary material, which is available to authorized users.

H.-P. Rusterholz $(\bowtie) \cdot$ C. Verhoustraeten · B. Baur Department of Environmental Sciences, Section of Conservation Biology, University of Basel, St. Johanns-Vorstadt 10, 4056 Basel, Switzerland

e-mail: hans-peter.rusterholz@unibas.ch
Keywords Deciduous forest - Recreational disturbance · Restoration · Species composition · Sport climbing

\section{Introduction}

Exposed limestone cliffs in Central Europe harbor unique plant, bryophyte, lichen, and invertebrate communities (Zoller 1989; Larson and others 2000; Ursenbacher and others 2010). The high species richness, large number of rare species, and rarity of the habitat type give these cliffs a high conservation value (Wassmer 1998; Baur 2003). The Fauna-FloraHabitat guidelines of the European Union consider limestone cliffs as habitats of "European importance" (Council Directive 92/43/EEC). During past decades, however, recreational activities, including sport climbing, bouldering, hiking, and mountain biking, are increasingly threatening the sensitive cliff vegetation. Rock climbing is popular in these mountain areas at low elevation, where this sport can be performed during the whole year (Hanemann 2000).

Damage to vascular plant vegetation due to rock climbing was recorded at the face of limestone cliffs in the Jura Mountains in northwestern Switzerland and on other rocky cliffs in Germany and North America (McMillan and Larson 2002; Müller and others 2004; Rusterholz and others 2004). Damage included a decrease of vegetation cover and extinction or extirpation of species in the plant community sensitive to disturbance. At the cliff base, the aboveground vegetation is reduced and the soil compacted as result of human trampling by climbers and the people securing the climbers. Soil compaction led to an increase in soil bulk density and a decrease in soil porosity, changed the water and temperature regime, and altered the soilnutrient composition (Kozlowski 1999; Kissling and others 2009). 
Restoration measures, such as visitor management and the opening of the canopy, are planned to preserve the ecological integrity of limestone cliffs (Müller and others 2006). The success of forest restoration at the cliff base depends mainly on the presence of viable seeds in the soil seed bank and on other propagules, such as tubers and bulbs (Leck 1989; Maranon 1998). The persistence of seeds in the soil is influenced by the extent of seed predation, microbial decay, seed size and shape, soil characteristics, and temperature (Thompson and others 1998; Forcella 2003; Mickelson and Grew 2006). Soil compaction by human trampling alters soil characteristics, which in turn affects the persistence of seeds (Liddle 1997). However, data on the impact of human trampling on the density and species composition of seeds in the soil seed banks of forests are rarely available (for exceptions, see Zabinski and others 2000; Amrein and others 2005; Roovers and others 2006).

We assessed the impact of human trampling at the base of limestone cliffs in the Jura Mountains on the ground vegetation and soil seed bank to provide basic information for restoration measures. In particular, we examined the composition of aboveground forest vegetation and density and species composition of seeds in the soil seed bank at the base of climbed and unclimbed cliffs. We addressed the following questions:

1. How does human trampling affect the cover and composition of the aboveground forest vegetation at the base of limestone cliffs?

2. Are the density and species composition of seeds in the soil seed bank altered in heavily trampled areas at the base of limestone cliffs?

\section{Material and Methods}

\section{Study Sites}

The cliffs of the Jura Mountains are small and isolated and mostly surrounded by beech forests or xerothermic oak forests. A variety of plants growing on these cliffs are interglacial or postglacial relics with a recent mediterranean or arctic-alpine distribution (Walter and Straka 1970). More than 2000 sport climbing routes with fixed protection bolts have been installed on 48 limestone cliffs in the region of Basel, Switzerland (Andrey and others 1997). Approximately $60 \%$ of these climbing routes were opened between 1989 and 1995 .

The study was conducted at the bases of eight limestone cliffs situated in deciduous forests in the Jura Mountains south of Basel (Table 1). The cliffs are referred to as Schartenfluh, Schauenburgfluh, Falkenfluh, Pelzmühletal,
Hanslifelsen, Chuenisberg, Wolfenried, and Rappenfels. The former four cliffs were affected by intensive yearround recreational activities, mainly rock climbing but also hiking and picnicking. Information on duration and intensity of climbing was obtained from Andrey and others (1997). The intense recreational activities resulted in visible damage to the ground vegetation, shrubs, and trees at the base, in the face, and on the top of the cliffs (Baur 2003; Rusterholz and others 2004). The remaining four cliffs were not affected by rock climbing and thus served as controls (Table 1). Forests surrounding the disturbed and control cliffs consist of different stands belonging to the Fagetum and Tilietum associations (Table 1). The forests did not differ in type of forest vegetation, soil type, and management condition. The cliffs are $1.2-14 \mathrm{~km}$ apart. Mean annual rainfall ranges from 800 to $1200 \mathrm{~mm}$, and mean annual temperatures range from 6 to $9^{\circ} \mathrm{C}$ (MeteoSwiss 2005a, b).

\section{Aboveground Vegetation}

To examine the under-storey vegetation and soil seed bank at the cliffs' base, we selected at each cliff two plots measuring $12 \times 3 \mathrm{~m}$ adjacent to the cliff face. The distances between the two plots ranged from 20 to $70 \mathrm{~m}$. The species composition of the under-storey vegetation was assessed in each plot in spring and autumn of 2007 and 2008. In addition, total plant cover in each plot was visually estimated in five randomly chosen subplots measuring $1 \times 1 \mathrm{~m}$ using the Domin scale (MüllerDombois and Ellenberg 2002). To complete the species list of each plot, we recorded all plant species occurring in the adjacent $12 \mathrm{~m}$-wide by $5 \mathrm{~m}$-high strip on the rock face and in a plot measuring $12 \times 5 \mathrm{~m}$ on the plateau of the cliff.

\section{Soil Seed Bank}

To examine the seed bank at the base of the cliff, soil samples were taken in June 2008. In each plot, three lines running parallel to the cliff face were installed at distances of $0.5,1.5$, and $2.5 \mathrm{~m}$ from the base of the cliff. The soil samples were taken at distances of $1 \mathrm{~m}$ along each line. After removing the leaf-litter layer, soil samples were collected to a depth of $5 \mathrm{~cm}$ using a metal cylinder of $5 \mathrm{~cm}$ diameter (soil volume $100 \mathrm{~cm}^{3}$ ). In some cases, however, the rocky ground made soil sampling impossible (see Appendix 1 in Supplementary Material). The 7 to 16 soil samples from each sampling line were pooled and mixed and sieved (6.3 and $4 \mathrm{~mm}$-wide mesh) to remove stones, and the volume of the sieved soil was determined. The soil samples were stored for 1 week in the dark at $4^{\circ} \mathrm{C}$ to break any dormancy (Brown 1992). 


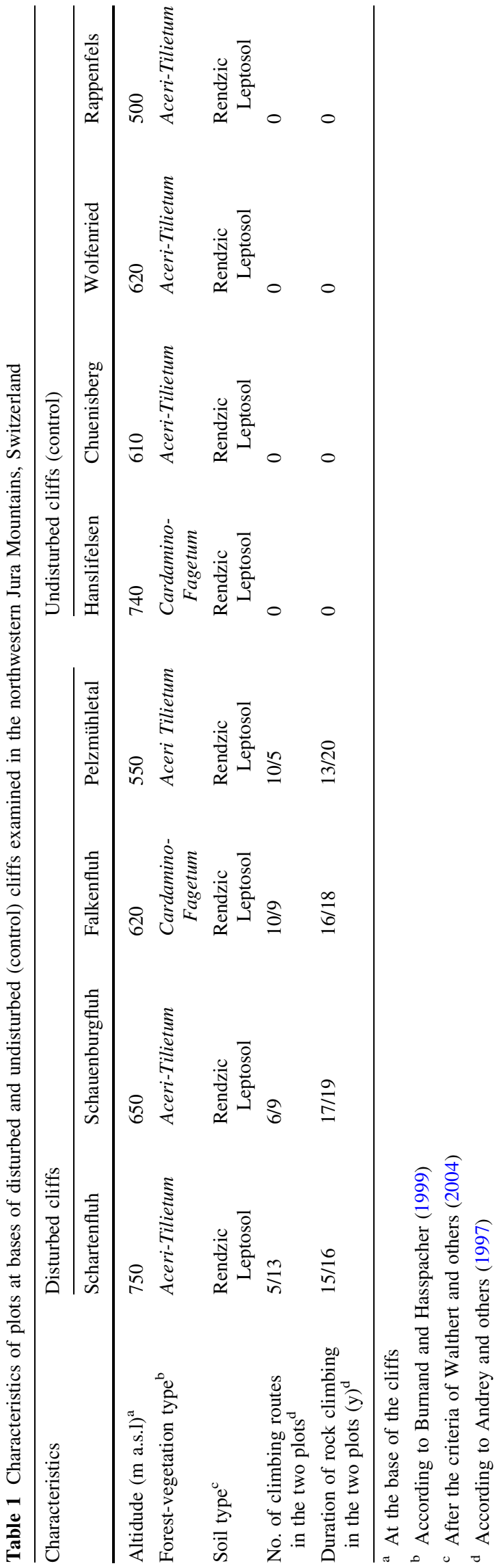

The seedling-emergence method was used to determine the number of viable seeds for each species in the soil (Ter Heerdt and others 1996). We used the method of Ter Heerdt and others (1996) for several reasons: The seedlingemergence method provides a greater germination rate of viable seeds in the soil and thus increases the number of seedlings compared with the classic seedling-emergence method without sieving the soil samples (Brown 1992). This method is nowadays the most frequently used technique to investigate the soil seed bank (Bossuyt and Honnay 2008).

The soil samples were washed through a coarse $(2 \mathrm{~mm}$ wide mesh) and a fine (0.2 mm-wide mesh) sieve to remove soil particles and plant roots. Subsequently the soil samples from each distance line were spread out on a $3 \mathrm{~cm}$ thick layer of potting soil in a $55 \times 35-\mathrm{cm}$ seed tray, forming an approximately $1 \mathrm{~mm}$ - to $2 \mathrm{~mm}$-thick layer. This resulted in a total of 48 seed trays. A further six seed trays filled only with potting soil were used as controls for potential contamination of the soil used and for external seed contamination. All trays were randomly arranged on shelves kept outdoors to provide natural variation in local climatic conditions to germinating seeds. The seed trays were kept continuously moist by daily watering. To avoid differences in light exposure, the positions of the trays were changed every 5 days. Every 3 days all trays were checked for seedlings. Newly emerged seedlings were determined (Muller 1978), counted, and removed from the tray. Unidentifiable seedlings were transplanted into pots and grown until species identification was possible. The germination test started in June 2008 and lasted 4 months until no further seedlings could be detected. At the end of the germination test, the soil was stirred up to allow new seedling emergence.

The germinating seeds were assigned to plant-strategy types according to Grime and others (1988). Furthermore, the seeds were assigned to different dispersal types using the criteria of Müller-Schneider (1986) and to different types of seed longevity according to Thompson and Grime (1979).

\section{Data Analyses}

We used R software [R Development Core Team, version 2.9 .1 (2009); Vienna, Austria] for all statistical analyses. Preliminary data analyses showed that the aboveground vegetation and seed-bank characteristics did not differ between the two plots of each cliff. We therefore combined the data from both plots for further analyses. Wilcoxon's sign rank tests were applied to examine whether total plant cover and number of plant species in aboveground vegetation differed between disturbed (trampled) cliffs and undisturbed cliffs. 
Possible effects of human trampling on total seed density and total plant-species richness were examined using a three-way analysis of covariance (ANCOVA) with the factors "treatment (disturbed vs. control)," "cliff," and "distance of sampling line to base of cliff" and the cofactors "volume of soil samples" and "number of soil samples collected along each sampling line." To avoid pseudoreplication, analyses were performed with the pooled data of each sampling line. If necessary, data were log-transformed to obtain normally distributed residuals and homogeneous group variance. The ANCOVA models were stepwise reduced as recommended by Crawley (2007).

Spearman rank correlation analyses were performed to examine possible effects of the duration and intensity of rock climbing on cover and plant-species richness of above-ground vegetation as well as on seed density and plant-species richness in the soil seed bank. Duration of rock climbing was expressed as the median of the year when the various climbing routes in each cliff area were installed (Andrey and others 1997). The extent of disturbance by rock climbing was expressed as density of climbing routes (the number of climbing routes per metre of horizontal rock face) in each area.

Detrended correspondence analyses (DCA) were used to examine whether human trampling affected the structure of the plant community of aboveground vegetation and soil seed bank using the software CANOCO version 4.5 (Ter Braak and Smilauer 2002). Contingency analysis was applied to examine differences between disturbed and undisturbed cliffs in the proportion of species belonging to the different plant-strategy types, dispersal types, and seed longevity. The simple-matching index was used to compare species composition of the seed bank with that of existing aboveground vegetation.

\section{Results}

\section{Aboveground Vegetation}

A total of 121 vascular plant species were recorded at the bases of the 8 limestone cliffs; 95 (79\%) of these species were found in disturbed cliffs, and 114 (94\%) were found in undisturbed cliffs (Appendix 2 in Supplementary Material). Total plant-species richness was marginally lower at the base of disturbed cliffs than at undisturbed cliffs (disturbed median $=53$ species [range 43-79] and control median $=68$ species [range 46-90]; z-score 1.94, $n=8, P=0.053)$. Furthermore, total plant cover was significantly decreased at the base of disturbed cliffs $(4 \%$ [range 2-6\%]) compared with undisturbed cliffs $(68 \%$ [10-92\%]; z-score 3.31, $n=8, P=0.005)$. However, total plant-species richness and total vegetation cover were correlated neither with duration of disturbance nor with intensity of rock climbing ( $P>0.18$ in all cases).

The first three axes of the multivariate analysis (DCA) explained $43.1 \%$ of the variation in plant-species data. The DCA also showed that the first axis (22.6\%) separated disturbed cliffs from undisturbed cliffs (z-score 2.17, $n=8, P=0.034$; Fig. 1a). Seven species (Aegopodium podagraria, Poa annua, Plantago major, Prunella vulgaris, Ranunculus acris, $R$. repens, and Stellaria media) occurred only in disturbed cliffs, whereas nine species (Athyrium felix-femina, Atropa-bella-donna, Daphne laureola, Dryopterix fils-mas, Genista pilosa, Hieracium pilosella, Ilex aquifolium, Leucanthemum adjustum, and Taxus baccata) were exclusively recorded in undisturbed cliffs (Fig. 1b).

Disturbance by rock-climbing activities caused a shift in the composition of species belonging to different plantstrategy types $\left(\chi^{2}=12.3\right.$, degrees of freedom $[d f]=3$, $P<0.01)$. A larger proportion of competitive and stresstolerant ruderal species (CSR) were found at the base of disturbed cliffs $(\mathrm{CSR}+29.2 \%)$ than at undisturbed cliffs $(\mathrm{CSR}+20.0 \%)$. In contrast, disturbed cliffs harbored a lower proportion of competitive species $(\mathrm{C}+41.0 \%)$ than undisturbed cliffs $(\mathrm{C}+49.7 \%)$.

\section{Soil Seed Bank}

A total of 1455 germinable seeds belonging to 56 vascular plant species emerged from the soil samples: 615 seeds (42\%) belonging to 48 species in the disturbed cliffs and 840 seeds $(58 \%)$ of 39 species in undisturbed cliffs (Appendix 3 in Supplementary Material). Seed density was lower at the base of disturbed cliffs (mean $\pm \mathrm{SE}$ $1237 \pm 217)$ than at undisturbed cliffs $(1607 \pm 112$; Table 2). Seed density also differed among the cliffs (Table 2). The highest seed density was recorded at the base of the undisturbed cliff Wolfenried $\left(2357 / \mathrm{m}^{2}\right)$, whereas the disturbed cliff Schartenfluh had the lowest seed density $\left(688 / \mathrm{m}^{2}\right)$. Seed density decreased with distance to the base of the cliff both at disturbed and undisturbed cliffs (Table 2).

Disturbed and undisturbed cliffs did not differ in plantspecies richness in the seed bank (Table 2), which ranged from 8.2 to $12.0(9.6 \pm 0.5)$ at the base of disturbed cliffs and from 6.5 to $13.0(9.7 \pm 0.6)$ at undisturbed cliffs. Plant-species richness in the seed bank differed among cliffs but was not affected by distance to the base of the cliff (Table 2). ANCOVA analyses showed that seed density and species richness were influenced neither by the number of soil samples taken nor by the volume of soil samples (all $P>0.23$ ). Total seed density was negatively correlated with the extent of human disturbance $\left(r_{\mathrm{s}}=\right.$ $-0.722, n=8, P=0.043$ ) and tended be negatively 
Fig. 1 DCA of the species composition of aboveground vegetation at the base of eight limestone cliffs in the Swiss Jura Mountains. a First and second DCA scores of the disturbed (filled symbols; $N=4)$ and undisturbed cliffs (open symbols; $N=4$ ) and b scores of the vascular species. $F a$ Falkenfluh, $S c$ Schauenburgfluh, $P e$ Pelzmühletal, $S a$ Schartenfluh, Ch Chuenisberg, $\mathrm{Ha}$ Hanslifelsen, Wo Wolfenried, $R a$ Rappenfels. For species abbreviations see Appendix 2 in Supplementary Material a

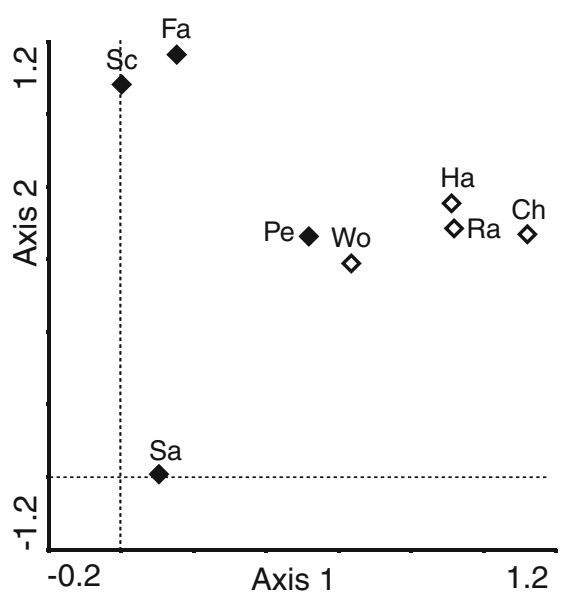

b

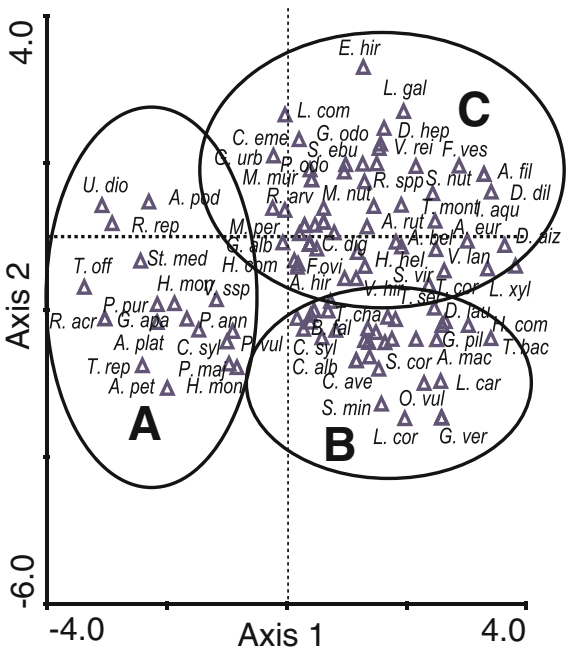

Table 2 Summary of ANCOVAs testing the effects of cliff (=locality), treatment (disturbed vs. control) and distance to cliff on seed density and plant-species richness in the soil seed bank

\begin{tabular}{lllll}
\hline Factor & Seed density & & \multicolumn{2}{c}{ Plant-species richness } \\
\hline Cliff & $\mathrm{F}_{6,14}=6.76$ & $P=0.002$ & $\mathrm{~F}_{6,14}=5.26$ & $P=0.006$ \\
Treatment & $\mathrm{F}_{1,14}=7.14$ & $P=0.018$ & $\mathrm{~F}_{1,14}=0.04$ & $P=0.856$ \\
Distance & $\mathrm{F}_{2,14}=3.86$ & $P=0.046$ & $\mathrm{~F}_{2,14}=2.45$ & $P=0.124$ \\
\hline
\end{tabular}

correlated with duration of human disturbance $\left(r_{\mathrm{s}}=\right.$ $-0.646, n=8, P=0.083)$. In contrast, species richness in the seed bank was correlated neither with extent nor duration of human disturbance (in both cases $P>0.36$ ).

The multivariate analysis (DCA) showed that the first three axes explained $38.7 \%$ of the variance in species composition in the seed bank and that plant-species composition in the seed bank tended to differ between disturbed and undisturbed cliffs (DCA-axis 1: z-score 1.88, $n=8$, $P=0.061$; Fig. 2a). Furthermore, multivariate analysis showed three highly distinct clusters of plant species (DCA-axis 1: $\mathrm{F}_{2,53}=20.58, P<0.0001$; DCA-axis 2: $\mathrm{F}_{2,53}=45.0, \quad P<0.0001 ; \quad$ DCA-axis $3: \quad \mathrm{F}_{2,53}=2.02$, $P=0.14$; Fig. 2b). The first cluster (A) is composed of plant species frequently found in the seed bank at the base of the highly disturbed cliff of Schartenfluh; the second cluster (B) is dominated by plant species of the base of the three remaining disturbed cliffs; and the third cluster (C) is mainly composed of plant species at the base of undisturbed cliffs (Fig. 2a, b).

Disturbance by rock-climbing activities resulted in an altered composition of plant species belonging to different plant strategy types $\left(\chi^{2}=80.1, \quad d f=3, \quad P<0.0001\right.$; Fig. 3a). A larger proportion of stress-tolerant and ruderal seeds were found at the base of disturbed cliffs $(\mathrm{S}+49 \%$,
$\mathrm{R}+27 \%)$ than at undisturbed cliffs $(\mathrm{S}+40 \%, \mathrm{R}+14 \%)$. Furthermore, a larger proportion of wind-dispersed seeds was recorded at the base of disturbed cliffs $(64 \%)$ than at the base of undisturbed cliffs $\left(53 \% ; \chi^{2}=31.0, d f=2\right.$, $P<0.001$; Fig. 3b). In addition, a larger proportion of transient seeds occurred at the base of disturbed cliffs (58\%) than undisturbed cliffs $\left(35 \% ; \chi^{2}=147.1, d f=2\right.$, $P<0.0001$; Fig. 3c). In contrast, disturbed and undisturbed cliffs did not differ in the number of plant species belonging to different plant-strategy types, dispersal types, and different types of longevity (all $P>0.31$ ).

\section{Species Composition of Aboveground Vegetation} and Soil Seed Bank

Considering both aboveground vegetation and seed bank, a total of 135 plant species were recorded at the base of the eight limestone cliffs examined: 121 species $(90 \%)$ in the aboveground vegetation and $56(41 \%)$ in the seed bank; 35 species $(26 \%)$ were found both in the aboveground vegetation and seed bank. Considering single cliffs, plant species exclusively found in the aboveground vegetation ranged from 36 to $80 \%$ of the total plant species recorded, whereas species found only in the seed bank ranged from 10 to $64 \%$. At the base of disturbed cliffs, 31 of 119 species $(26 \%)$ were found in both aboveground vegetation and seed bank; at undisturbed cliffs the corresponding figures were 25 of 122 species (20\%). The simple-matching similarity coefficient between aboveground vegetation and seed bank was remarkably high and ranged from 0.39 to 0.67 in disturbed and from 0.38 to 0.77 in undisturbed cliffs. Correspondingly, disturbed and undisturbed cliffs did not differ in similarity of species composition between aboveground vegetation and soil seed bank (z-score 0.46, $n=8, P=0.89$ ). 
Fig. 2 DCA of species composition of the soil seed bank at the base of eight limestone cliffs in the Swiss Jura Mountains. a First and second DCA scores of the disturbed (filled symbols; $N=4)$ and undisturbed cliffs (open symbols; $N=4$ ) and b scores of the vascular species. Fa Falkenfluh, Sc Schauenburgfluh, $P e$ Pelzmühletal, $\mathrm{Sa}$ Schartenfluh, $\mathrm{Ch}$ Chuenisberg, $\mathrm{Ha}$ Hanslifelsen, Wo Wolfenried, $R a$ Rappenfels. For species abbreviations see Appendix 3 in Supplementary Material
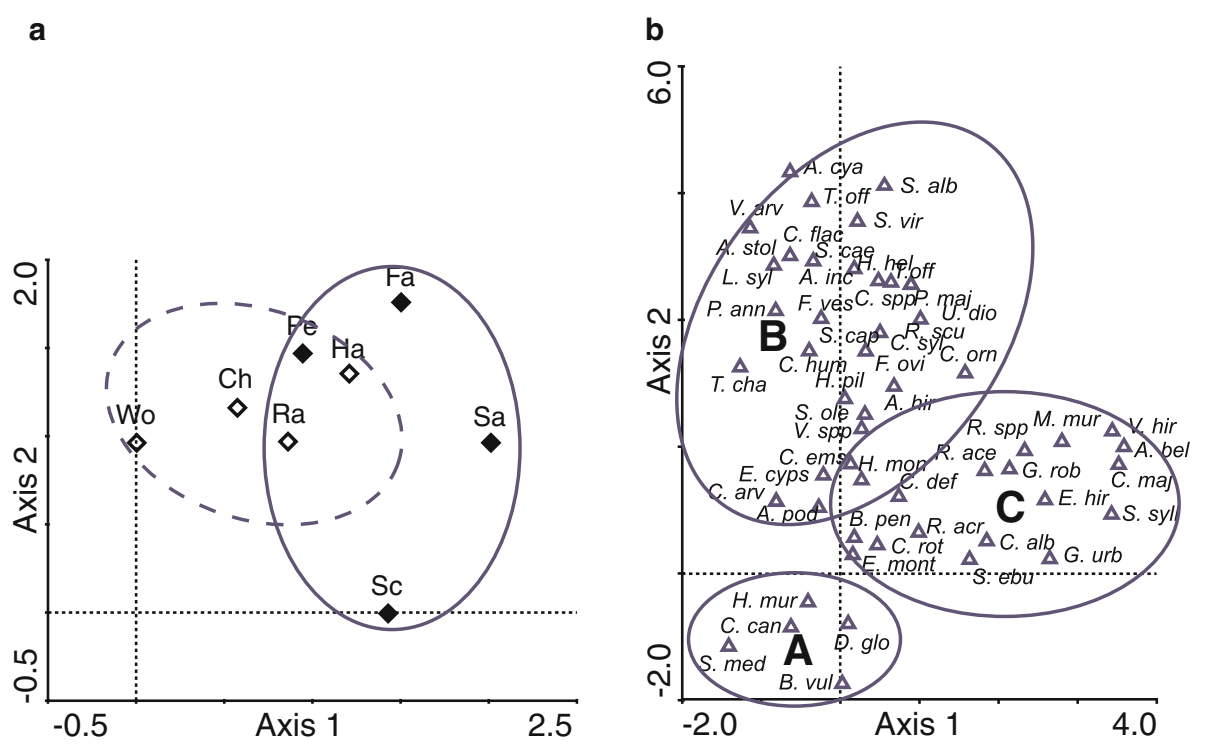

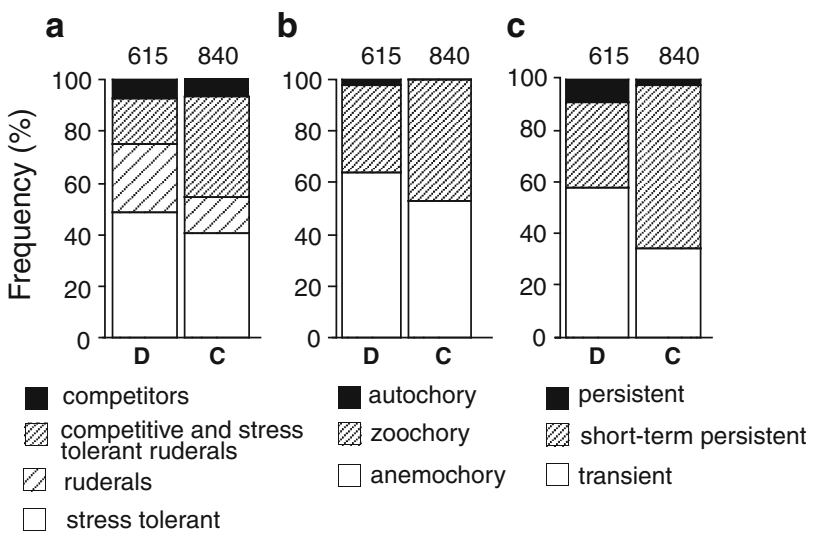

Fig. 3 Proportion of plant species belonging to a different plantstrategy, b seed-dispersal, and $\mathbf{c}$ seed-longevity types recorded at the base of disturbed $(D ; N=4)$ and undisturbed cliffs $(C ; N=4)$ in the Swiss Jura Mountains. Figures on the top of the bars indicate number of seeds

\section{Discussion}

The present study shows that long-term human trampling significantly decreases aboveground vegetation and alters the seed bank at the base of limestone cliffs in mixed beech and lime forests in northwestern Switzerland. Intensive human trampling is known to decrease the cover, height, and species richness of ground vegetation and to change the species composition in various ecosystems (Liddle 1997; Hill and Pickering 2009; Hegetschweiler and others 2009). In general, low-productive vegetation types, such as ground vegetation of spruce (Hamberg and others 2010) and beech forests (Amrein and others 2005; Kissling and others 2009; Bernhardt-Romermann and others 2011), are sensitive to trampling, whereas highly productive pastures are able to resist a high level of impact (Liddle 1997). The results of our study are in line with these findings. However, our study shows that the decreases in total species richness and cover of aboveground vegetation were not related to the duration and intensity of disturbance. Our results show that the specialized vegetation at the cliff base is sensitive to disturbance and degraded at low level of impact. This suggestion was supported by DCA analyses, which showed that long-term year-round human trampling transformed the characteristic forest vegetation into a degraded vegetation type dominated by trampling- and disturbance-tolerant plant species, including Dactylis glomerata, P. апnиa, P. major, S. media and Barbarea vulgaris, which do not belong to the typical forest species. They were unintentionally introduced in recent years by sport climbers and other visitors to the limestone cliffs (Pickering and Mount 2010).

\section{Soil Seed Bank}

In general, the seed density in forests is highly variable in space. For example, seed densities ranged from 3450 to 8700 seeds $/ \mathrm{m}^{2}$ in different mixed-beech forests in Belgium (Bossuyt and others 2002), from 298 to 3606 seeds $/ \mathrm{m}^{2}$ in beech forests in Germany (Schmidt and others 2009), and from 0.43 to 15630 seeds $/ \mathrm{m}^{2}$ in different deciduous forests in Canada (Leckie and others 2000). The seed densities found in our study are in the range of these estimates. However, differences in soil-sampling and germination methods should be taken into account when different studies on seed densities are compared. Seeds of different species vary in their germination requirements (Grime and others 1981). Differential climatic conditions in germination experiments may therefore contribute to the high variation in seed densities reported. The natural climatic 
conditions of our study are suitable for most of the species potentially occurring in the soil seed bank. The spatial aggregation of seeds in soil could be a further reason for the huge among-site variation in seed density reported in a variety of studies. Different soil-sampling schedules could, therefore, result in different seed densities (Ambrosio and others 2004; Plue and others 2010). We counteracted this effect by collecting a large number of small soil samples in each plot.

In our study, disturbance by human trampling decreased the density of the seed bank. Similarly, Zabinski and others (2000) found a lower seed density in disturbed areas than in control areas of pine forests. In contrast, seed densities were not affected by human trampling in two mixed-beech forests (Amrein and others 2005; Roovers and others 2006). Seed densities were even greater in forest areas disturbed by logging and forest-management activities than in control areas (Cohen and others 2004; Zobel and others 2007). It seems, therefore, that different types and magnitudes of disturbance influence the soil seed bank in different ways. Human trampling directly and indirectly affects the forest vegetation and thus results in soil modification, particularly in soil compaction (Liddle 1997). Loss of organic material and changes in physical soil conditions were the main factors responsible for the decreased seed density in disturbed areas of pine forests (Zabinski and others 2000). We found similar changes in chemical and physical soil characteristics in trampled areas at the base of the cliff. Human trampling decreased soil $\mathrm{pH}$, amount of leaf litter, and total amount of soil organic material at the base of the cliff Pelzmühletal (H.-P. Rusterholz 2004, unpublished data).

In our study, human trampling caused a shift in plantspecies composition in the soil seed bank: Seeds of stresstolerant and ruderal species occurred more frequently in disturbed than in undisturbed areas. Similar findings were reported in other forests with heavy recreational use (Zabinski and others 2000; Amrein and others 2005; Roovers and others 2006). It is generally assumed that forest soils contain few seeds of woody plants and that seeds of species occurring in forest edges, gaps, and clearings are abundant (Graber and Thompson 1978; Bossuyt and others 2002). The high dominance of seeds of stress-tolerant, ruderal, and anemochorous species found in our study was rather surprising, but it could be explained by the long-term impact of trampling and of propagule rain from climbers and other people visiting these cliffs. A large proportion of anemochorously dispersed seeds is characteristic for forest gaps (Booth and Larson 1998; Pakeman and Small 2005; Yan and others 2010). Stress-tolerant and ruderal plant species (e.g., Plantago major, Taraxacum officinale, and Poа аппиа) were also recorded in the seed bank of other forests
(Leckie and others 2000; Zabinski and others 2000; Amrein and others 2005). A high proportion of stresstolerant and ruderal species is, however, characteristic for forests with highly degraded soil conditions (Amrein and others 2005; Bossuyt and Honnay 2008).

In our study, plant-species composition of the seed bank differed from that of the aboveground vegetation. Dissimilarities between seed bank and aboveground vegetation have been reported for a variety of ecosystems (Chambers 1994; Bossuyt and others 2002). In forests, the majority of the aboveground vegetation species has transient seeds (Thompson 1992), which results in a low similarity between seed bank and aboveground vegetation composition. Furthermore, a decreased seed production of typical forest species (Falinska 1971; Rusterholz and others 2009), as well as changes in environmental conditions that control germination rate and seedling establishment, could decrease the establishment of typical forest species and thus explain the dissimilarity between seed bank and aboveground vegetation.

\section{Management Implications}

The protection of native forests is a main target of biodiversity conservation (Fearnside 2005). In forests of northwestern Switzerland, the base and plateau of limestone cliffs harbor an extraordinary assemblage of lichens, bryophytes, vascular plants, and animals and are therefore considered as local biodiversity hot spots (Zoller 1989; Baur 2003; Baur and others 2007). During past decades, these habitats are under increasing pressure through intensive recreational use. Seeds in the soil are often more tolerant to adverse conditions than other components of the propagule bank in the soil (Leck 1989). The availability of seeds in the soil seed bank is therefore generally assumed to be important for the regeneration of degraded natural habitats (Leck 1989; Thompson 1992; Maranon 1998). This study showed that revegetation from the seed bank would result in a shift of the vegetation composition in formerly disturbed sites. Other studies indicate that natural recovery of disturbed cliff bases resulted in degraded forest vegetation dominated by alien species (De Gruchy and others 2001; Matthes and others 2003; Bossuyt and Honnay 2008). Thus, active restoration measures, such as visitor management, opening of the canopy, and removal of ruderal and alien plant species, will be required to return degraded forest vegetation close to its original state. Furthermore, our findings underscore the importance of undisturbed natural forest areas for ensuring seed flux into disturbed forest sites. These results are the basis for developing management plans for heavily trampled areas at the base of limestone cliffs. 
Acknowledgments We thank A. Baur, S. Gallet, C. Pickering, and two anonymous reviewers for valuable comments on the manuscript.

\section{References}

Ambrosio L, Iglesias L, Marin C, Del Monte JP (2004) Evaluation of sampling methods and assessment of the sample size to estimate the weed seed bank in soil, taking into account spatial variability. Weed Research 44:224-236

Amrein D, Rusterholz HP, Baur B (2005) Disturbance of suburban Fagus forests by recreational activities: effects on soil characteristics, above-ground vegetation and seed bank. Applied Vegetation Science 8:175-182

Andrey P, Tscharner N, Luisier A (1997) Fluebible, Kletterführer Basler Jura. Dynamo Productions, Binningen

Baur B (2003) Freizeitaktivitäten im Baselbieter Wald. Ökologische Auswirkungen und ökonomische Folgen. Verlag des Kantons Basel-Landschaft, Liestal

Baur B, Fröberg L, Müller SW (2007) Effect of rock climbing on the calcicolous lichen community of limestone cliffs in the northern Swiss Jura Mountains. Nova Hedwigia 85:429-444

Bernhardt-Romermann M, Gray A, Vanbergen AJ, Berges L, Bohner A, Brooker RW et al (2011) Functional traits and local environment predict vegetation responses to disturbance: a pan-European multi-site experiment. Journal of Ecology 99:777-787

Booth BD, Larson DW (1998) The role of seed rain in determining the assembly of a cliff community. Journal of Vegetation Science 9:657-668

Bossuyt B, Honnay O (2008) Can the seed bank be used for ecological restoration? An overview of seed bank characteristics in European communities. Journal of Vegetation Science 19:875-884

Bossuyt B, Heyn M, Hermy M (2002) Seed bank and vegetation composition of forest stands of varying age in central Belgium: consequences for regeneration of ancient forests. Plant Ecology 162:33-48

Brown D (1992) Estimating the composition of a forest seed bank. A comparison of the seed extraction and seedling emergence method. Canadian Journal of Botany 70:1603-1612

Burnand J, Hasspacher B (1999) Waldstandorte beider Basel. Quellen und Forschungen zur Geschichte und Landeskunde des Kantons Basel-Landschaft. Band 72. Verlag des Kantons Basel-Landschaft, Liestal

Chambers JC (1994) A day in the life of a seed. Annual Review of Ecology and Systematics 25:263-292

Cohen S, Braham R, Sanchez F (2004) Seed bank viability in disturbed longleaf pine sites. Restoration Ecology 12:503-515

Council Directive 92/43/EEC. http://ec.europa.eu/environment/nature/ legislation/habitatsdirective/index_en.html

Crawley MJ (2007) The R book. Wiley, Chichester

De Gruchy MA, Matthes U, Gerrath JA, Larson DW (2001) Natural recovery and restoration potential of severely disturbed talus vegetation at Niagara Falls: assessment using a reference system. Restoration Ecology 9:311-325

Falinska K (1971) An estimate of diaspore production in the ecosystem of a mixed oak-hornbeam forest (Querco-Carpinetum) in the Bialowieza national park. Ekologia Polska 19:525-561

Fearnside PM (2005) Deforestation in Brazilian Amazonia: history, rates and consequences. Conservation Biology 19:680-688

Forcella F (2003) Debiting the seed bank: priorities and predictions. Aspects of Applied Biology 69:151-162

Graber RE, Thompson DF (1978) Seeds in the organic layers and soil of four beech-birch-maple stands. United States Forest Service Research Paper NE-401
Grime JP, Mason G, Curtis AV, Rodman J, Band SR, Mowforth MAG et al (1981) A comparative study of germination characteristics in a local floral. Journal of Ecology 69:1017-1059

Grime JP, Hodgson JG, Hunt R (1988) Comparative plant ecology. Hyman, London

Hamberg L, Malmivaara-Lamsa M, Lehvavirta S, O’Hara RB, Kotze DJ (2010) Quantifying the effects of trampling and habitat edges on forest understory vegetation-a field experiment. Journal of Environmental Management 91:1811-1820

Hanemann B (2000) Cooperation in the European mountains. 3. The sustainable management of climbing areas in Europe. International Union for Conservation of Nature, Gland

Hegetschweiler KT, Van Loon N, Ryser A, Rusterholz HP, Baur B (2009) Effects of fireplaces on forest vegetation and amount of woody debris in suburban forests in Northwestern Switzerland. Environmental Management 43:299-310

Hill R, Pickering CM (2009) Differences in resistance of three subtropical vegetation types to experimental trampling. Journal of Environmental Management 90:1305-1312

Kissling M, Hegetschweiler KT, Rusterholz HP, Baur B (2009) Shortterm and long-term effects of human trampling on above-ground vegetation, soil density, soil organic matter and soil microbial processes in suburban beech forests. Applied Soil Ecology 42:303-314

Kozlowski TT (1999) Soil compaction and growth of woody plants. Scandinavian Journal of Forest Research 14:596-619

Larson DW, Matthes U, Kelley PE (2000) Cliff Ecology. Pattern and process in cliff ecosystems. Cambridge University Press, Cambridge

Leck MA (1989) Wetland seed banks. In: Leck MA, Parker VT, Simpson RL (eds) Ecology of seed banks. Academic, London, pp 283-305

Leckie S, Vellend M, Bell G, Waterway MJ, Lechowicz MJ (2000) The seed bank in old-growth, temperate deciduous forest. Canadian Journal of Botany 78:181-192

Liddle M (1997) Recreation ecology. Chapman Hall, London

Maranon T (1998) Soil seed bank and community dynamics in an annual-dominated Mediterranean salt-marsh. Journal of Vegetation Science 9:371-378

Matthes U, Gerrath JA, Larson DW (2003) Experimental restoration of disturbed cliff-edge forests in Bruce Peninsula National Park, Ontario, Canada. Restoration Ecology 11:174-184

McMillan MA, Larson DW (2002) Effects of rock climbing on the vegetation of the Niagara escarpment in southern Ontario, Canada. Conservation Biology 16:389-398

MeteoSwiss (2005a) Normwerte 1961-90 der Lufttemperatur. Federal Office of Meteorology and Climatology MeteoSwiss. http:// www.meteoschweiz.ch. Accessed 2 Nov 2008

MeteoSwiss (2005b) Normwerte 1961-90 der Niederschlagssumme. Federal Office of Meteorology and Climatology MeteoSwiss. http://www.meteoschweiz.ch. Accessed 2 Nov 2008

Mickelson JA, Grew WE (2006) Effect of soil water content on wild oat (Avena fatua) seed mortality and seedling emergence. Weed Science 54:255-262

Muller FM (1978) Seedlings of the north-western European flora: a flora of seedlings. Junk, The Hague

Müller S, Rusterholz HP, Baur B (2004) Rock climbing alters the vegetation of limestone cliffs in the northern Swiss Jura Mountains. Canadian Journal of Botany 6:862-870

Müller S, Rusterholz HP, Baur B (2006) Effects of forestry practices on relict plant species on limestone cliffs in the northern Swiss Jura mountains. Forest Ecology and Management 237:227-236

Müller-Dombois D, Ellenberg H (2002) Aims and methods of vegetation ecology. Wiley, New York

Müller-Schneider P (1986) Verbreitungsbiologie der Blütenpflanzen Graubündens. Heft 85. Veröffentlichungen des Gebobotanischen Institutes der ETH. Stiftung Rübel, Zürich 
Pakeman RJ, Small JL (2005) The role of seed bank, seed rain and the timing of disturbance in gap regeneration. Journal of Vegetation Science 16:121-130

Pickering CM, Mount A (2010) Do tourists disperse weed seed? A global review of unintentional human-mediated terrestrial seed dispersal on clothing, vehicles and horses. Journal of Sustainable Tourisms 18:239-256

Plue J, Goyens G, Van Meirvenne M, Verheyen K, Hermy M (2010) Small-scale seed-bank patterns in a forest soil. Seed Science Research 20:13-22

R Development Core Team (2009) $R$ : A language and environment for statistical computing. R Foundation for Statistical Computing, Vienna

Roovers P, Bossuyt B, Igodt B, Hermy M (2006) May seed banks contribute to vegetation restoration on paths in temperate deciduous forest? Plant Ecology 187:25-38

Rusterholz HP, Müller SW, Baur B (2004) Effects of rock climbing on plant communities on exposed limestone cliffs in the Swiss Jura mountains. Applied Vegetation Science 7:35-40

Rusterholz HP, Kissling M, Baur B (2009) Disturbances by human trampling alter the performance, sexual reproduction and genetic diversity in a clonal woodland herb. Perspectives in Plant Ecology Evolution and Systematics 11:17-29

Schmidt I, Leuschner C, Molder A, Schmidt W (2009) Structure and composition of the seed bank in monospecific and tree speciesrich temperate broad-leaved forests. Forest Ecology and Management 257:695-702

Ter Braak CJF, Smilauer P (2002) CANOCO reference manual and CanoDraw for Windows: Software for canonical community ordination (version 4.5). Microcomputer Power, Ithaca

Ter Heerdt GN, Verweij GL, Bekker RM, Bakker JP (1996) An improved method for seed-bank analysis: seedling emergence after removing the soil by sieving. Functional Ecology 10:144-151

Thompson K (1992) The functional ecology of seed banks. In: Fenner $M$ (ed) Seeds: the ecology of regeneration in plant communities. $\mathrm{CAB}$ International, Wallingford
Thompson K, Grime JP (1979) Seasonal variation in the seed bank of herbaceous species in ten contrasting habitats. Journal of Ecology 67:893-921

Thompson K, Bakker JP, Bekker RM, Hodgson JG (1998) Ecological correlates of seed persistence in soil in the north-west European flora. Journal of Ecology 86:163-169

Ursenbacher S, Alvarez C, Armbruster GFJ, Baur B (2010) High population differentiation in the rock-dwelling land snail (Trochulus caelatus) endemic to the Swiss Jura Mountains. Conservation Genetics 4:1265-1271

Walter H, Straka H (1970) Arealkunde. Floristisch-historische Geobotanik. Verlag Eugen Ulmer, Stuttgart

Walthert L, Zimmermann S, Blaser P, Luster J, Lüscher P (2004) Waldböden der Schweiz. Band 1. Grundlagen und Region Jura. Eidgenössische Forschungsanstalt WSL, Birmensdorf. Hep Verlag, Bern

Wassmer A (1998) Zur Felsenflora des östlichen Kettenjuras. Grundlagen und Berichte zum Naturschutz. Band 17. Baudepartement. Sektion Natur und Landschaft, Aargau

Yan QL, Zhu JJ, Zhang JP, Yu LZ, Hu ZB (2010) Spatial distribution pattern of soil seed bank in canopy gaps of various sizes in temperate secondary forests, Northeast China. Plant and Soil 329:469-480

Zabinski C, Wojtowicz T, Cole D (2000) The effects of recreational disturbance on subalpine seed banks in the Rocky Mountains of Montana. Canadian Journal of Botany 78:577-582

Zobel M, Kalamees R, Pussa K, Roosaluste E, Moora M (2007) Soil seed bank and vegetation in mixed coniferous forest stands with different disturbance regimes. Forest Ecology and Management 250:71-76

Zoller H (1989) Die Verarmung der Pflanzenwelt. In: Imbeck-Löffler P (ed) Natur aktuell, Lagebericht zur Situation der Natur im Kanton Basel-Landschaft im Jahr 1988. Verlag des Kantons Basel-Landschaft, Liestal, pp 217-246 